\title{
STUDENT RECEPTIVENESS TO KAHOOT! IN HIGHER EDUCATION
}

\author{
A. Pires ${ }^{1}$, S. Pais ${ }^{1}$, L. Chagas ${ }^{2}$ \\ ${ }^{1}$ Instituto Politécnico de Leiria (PORTUGAL) \\ ${ }^{2}$ Universidade de Lisboa (PORTUGAL)
}

\begin{abstract}
The use of technology in higher education has been increasing in the past few years and new online tools have emerged for very different purposes. Kahoot! is an example of a platform that can be used for reviewing content and motivating students for learning.

Our research is based on data from a quantitative survey conducted in the previous school year and the participants were 86 undergraduate students from a Portuguese higher education institution. The preliminary results of the survey showed that students are very receptive to this tool and highly recommend it, as it promotes motivation. Other studies have shown that higher education students are usually receptive to web tools and consider technology can positively impact learning.

To better understand students' responses to the platform, in this study we aim at analysing the results according to area of study and investigating new correlations between variables, specifically (i) gender vs receptiveness to Kahoot!, (ii) gender vs recommendation of its use and (iii) technology readiness vs receptiveness to Kahoot!.
\end{abstract}

Keywords: higher education; web tools; gender; technology readiness; technology receptiveness.

\section{INTRODUCTION}

As in our days interactive technologies tend to become more prevalent and democratic in terms of their availability and affordability, learning contexts, including higher education, have witnessed a growing resort to gamification elements in order to increase students' motivation and engagement [1]. These gamification techniques, which can be described as the design, implementation and use of game mechanics in non-gaming contexts [2] started with student response systems (SRSs) and online student response systems (OSRSs), that evolved into contemporary game-based student response systems (GSRSs) [3] [4].

The main advantages of GSRSs in comparison with SRSs and OSRSs are the possibility of immediate interaction between the users and the establishment of a rewarding system [5]. GSRSs such as Kahoot! integrate gamification techniques such as graphics, animation, audio and the use of score in order to activate the students' previous knowledge and evaluate their performance while they play and learn [6] [7]. Games and game technologies can enhance learning, as students become so motivated and engaged that they are not aware that they are learning while they are playing [3].

Several authors have studied students' acceptance to the integration of technology in education in elearning or b-learning contexts, as well as other technology-enhanced environments. However, few studies investigate the relationship between gender / area of study and game-based learning acceptance, specifically, hence the relevance of our research.

\section{METHODOLOGY}

Aiming at investigating students' perspectives on the use of Kahoot! in higher education, the authors conducted a survey to assess their perception regarding motivation for learning. The curricular units involved in the study were Statistics/Mathematics and English and for the conclusion of each of the syllabus topic (three in total), the authors decided to develop an online quiz as a revision tool. All Kahoot! quizzes were applied at the end of the lecture and lasted for 20 minutes, approximately. The preliminary results of that survey showed that students are very receptive to this tool and find it motivating, so they recommend its use [8]. 
Following the results of this previous study, in which $93 \%$ of the respondents considered the use of Kahoot! in classes as having been important or very important, in the current study the authors intend to deepen the analysis by trying to find out if there any differences in terms of students' responses in the two areas of study, namely English and Mathematics. Additionally, new correlations between variables are investigated, such as (i) gender vs receptiveness to Kahoot!, (ii) gender vs recommendation of use and (iii) technology readiness vs receptiveness to Kahoot!.

The statistical treatment of the data was performed using the Statistical Package for the Social Sciences (SPSS), version 25.0. Descriptive statistics (mean, median and standard deviation) were computed to examine the results that were obtained in the different areas of study. A multivariate analysis was also performed in order to understand the relationship between different variables, firstly analysed through descriptive statistics. At the multivariate level, contingency tables were used in order to analyse pairs of variables and verify independency tests, through Pearson's Chi-Squared [9], with $\alpha=5 \%$ (significance level):

$$
\chi^{2}=\sum_{j=1}^{m} \sum_{k=1}^{n} \frac{\left(n_{j k}-\frac{n_{j .} n_{. k}}{N}\right)^{2}}{\frac{n_{j .} n_{. k}}{N}}
$$

Figure 1. Chi-Square Statistics.

\subsection{Respondents}

The respondents are 86 undergraduate students from a Portuguese higher education institution. From the 86 respondents, $66(77 \%)$ are female and 20 male $(23 \%)$, as shown in the table below (Table 1$)$.

Table 1. Gender of respondents.

\begin{tabular}{l|c}
\hline \hline & Respondents \\
\hline Male & 20 \\
\hline Female & 66 \\
\hline Total & 86 \\
\hline \hline
\end{tabular}

\section{RESULTS}

As mentioned before, following the previous article regarding student motivation with Kahoot, the authors decided to go further in the study of the different items. More specifically, the answers to the questions were analysed according to different areas of study. The highest mean score in the English for Recreation IV subject is related to item 1 "I feel comfortable using electronic gadgets" ( $m=5,00$, sd $=0,000$ ). On the other hand, in both English II and Statistical Analysis, the highest mean score regards item 4 "It was fun using Kahoot!" ( $m=4.79, s d=0.426$ and $m=4.65, s d=0.555$, respectively).

As far as the lowest mean scores are concerned, results converge in the three subjects with item 3 "Using Kahoot! will contribute to having a better grade in the CU". The results were $m=3.61, s d=1.092$ in English for Recreation IV, $m=3.93, s d=0.917$ in English II and $m=3.43, s d=0.983$ for Statistics, as shown in the table below (Table 2). 
Table 2. Results of individual survey according to curricular unit.

\begin{tabular}{|c|c|c|c|c|c|c|c|c|c|}
\hline & \multicolumn{3}{|c|}{ English for Recreation IV } & \multicolumn{3}{|c|}{ English II } & \multicolumn{3}{|c|}{ Statistical Analysis } \\
\hline & $\begin{array}{l}\text { Mean } \\
(1 \text { to } 5)\end{array}$ & Std Dev & Median & $\begin{array}{c}\text { Mean } \\
(1 \text { to } 5)\end{array}$ & Std Dev & Median & $\begin{array}{c}\text { Mean } \\
(1 \text { to } 5)\end{array}$ & Std Dev & Median \\
\hline $\begin{array}{l}1 \text { - I feel comfortable using } \\
\text { electronic gadgets. }\end{array}$ & 5.00 & 0.000 & 5 & 4.57 & 0.514 & 5 & 4.63 & 0.708 & 5 \\
\hline $\begin{array}{l}2 \text { - I believe that Kahoot! } \\
\text { contributed to consolidate } \\
\text { the contents of the CU. }\end{array}$ & 3.94 & 1.162 & 4 & 4.21 & 0.802 & 4 & 4.09 & 0.875 & 4 \\
\hline $\begin{array}{l}3 \text { - Using Kahoot! will } \\
\text { contribute to having a better } \\
\text { grade in the CU. }\end{array}$ & 3.61 & 1.092 & 3 & 3.93 & 0.917 & 4 & 3.43 & 0.983 & 3 \\
\hline 4 - It was fun using Kahoot!. & 4.78 & 0.548 & 5 & 4.79 & 0.426 & 5 & 4.65 & 0.555 & 5 \\
\hline $\begin{array}{l}5 \text { - The response time in } \\
\text { Kahoot! was adequate. }\end{array}$ & 4.50 & 0.707 & 5 & 4.07 & 1.072 & 4 & 4.04 & 0.951 & 4 \\
\hline $\begin{array}{l}6 \text { - I find it important to be } \\
\text { able to see the scoreboard. }\end{array}$ & 4.39 & 0.850 & 5 & 4.07 & 0.730 & 4 & 3.81 & 1.150 & 4 \\
\hline $\begin{array}{l}7 \text { - I recommend using } \\
\text { Kahoot! in the classroom. }\end{array}$ & 4.33 & 0.840 & 5 & 4.57 & 0.646 & 5 & 4.41 & 0.659 & 4.5 \\
\hline $\begin{array}{l}8 \text { - It contributes to a more } \\
\text { positive attitude towards } \\
\text { English/ Mathematics. }\end{array}$ & 4.39 & 0916 & 5 & 4.36 & 0.929 & 4.5 & 4.17 & 1.060 & 4 \\
\hline $\begin{array}{l}9 \text { - It makes learning more } \\
\text { challenging, interesting and } \\
\text { stimulating. }\end{array}$ & 4.44 & 0.922 & 5 & 4.29 & 0.611 & 4 & 4.22 & 0.793 & 4 \\
\hline $\begin{array}{l}10 \text { - It provides a less rigid } \\
\text { learning method making it } \\
\text { more interactive and } \\
\text { interesting. }\end{array}$ & 4.56 & 0.511 & 5 & 4.50 & 0.760 & 5 & 4.37 & 0.623 & 4 \\
\hline $\begin{array}{l}11 \text { - It contributes towards } \\
\text { more active, lively and } \\
\text { dynamic classes. }\end{array}$ & 4.67 & 0.485 & 5 & 4.43 & 0.646 & 4.5 & 4.50 & 0.575 & 5 \\
\hline $\begin{array}{l}12 \text { - It facilitates the } \\
\text { interaction between lecturer } \\
\text { and student. }\end{array}$ & 4.39 & 1.092 & 5 & 4.5 & 1.019 & 5 & 3.98 & 0.879 & 4 \\
\hline $\begin{array}{l}13 \text { - I find it important for } \\
\text { lecturers to use different } \\
\text { strategies such as Kahoot! in } \\
\text { the classroom. }\end{array}$ & 4.50 & 0.785 & 5 & 4.43 & 1.158 & 5 & 4.48 & 0.720 & 5 \\
\hline
\end{tabular}

In order to observe the non/existence of independency among variables, multivariate analysis, was also performed using the Pearson Chi-Squared Test. Contingency tables' analyses have been used, through the independency test of Pearson Chi-Squared, in order to understand if:

- there are relationships between different variables and the curricular units that should be considered;

- there are relationships between different variables and the gender that should be considered;

- there are relationships between variable 2 ("I consider the use of Kahoot! in classes to be important") and variable 3 ("I feel comfortable using electronic gadgets") that should be considered $(p$-value $=0.618)$.

The results show that for a significance level $(\alpha)$ of $5 \%$, all the crossings obtained a $p$ value higher than 0.05 , which means that there is no relationship between the variables when crossed with the curricular units and with the gender (Table 3 ). 
Table 3. Variables crossed with curricular units and gender.

\begin{tabular}{l|c|c}
\hline \hline \multirow{2}{*}{ Variables } & Curricular units & Gender \\
\cline { 2 - 3 } & $\begin{array}{c}\text { Pearson Chi- } \\
\text { Squared Test }\end{array}$ & $\begin{array}{c}\text { Pearson Chi- } \\
\text { Squared Test }\end{array}$ \\
\hline 1- I recommend using Kahoot! In the classroom & $(=0.293)$ & $(=0.551)$ \\
\hline 2- I consider the use of Kahoot! in classes to be important & $(=0.158)$ & $(=0.105)$ \\
\hline 3- I feel comfortable using electronic gadgets & $(=0.550)$ & $(=0.701)$ \\
\hline \hline
\end{tabular}

\section{CONCLUSIONS}

The findings suggest that despite being at ease with electronic devices and considering the integration of technological tools in class to be entertaining, students are somehow reluctant to acknowledge that platforms such as Kahoot can be an asset to their performance. Even though this tool was used in class for content revision, students do not feel confident about it helping improve their grade. Other studies suggest, however, that this tool can contribute to improving students' academic results [10], [11].

Another important result refers to the non existence of significant differences in terms of gender and area of study (English and Mathematics) regarding the variables examined. Other studies [12] had similar results regarding gender.

With this study, we hope to contribute to the discussion on the use of digital tools and their usefulness in class.

\section{REFERENCES}

[1] S. A. Licorish, H. E. Owen, B. Daniel, \& J. L. George. "Students' perception of Kahoot!'s influence on teaching and learning". Research and Practice in Technology Enhanced Learning, 13(1), 9, pp.1-23,2018. doi: 10.1186/s41039-018-0078-8

[2] S. Deterding, D. Dixon \& R. Khaled. "Gamification: toward a definition". In The ACM CHI Conference on Human Factors in Computing Systems, pp. 12-15, 2011.

[3] A. I. Wang. "The wear out effect of a game-based student response system". Computers \& Education, 82, pp. 217-227, 2015. doi: 10.1016/j.compedu.2014.11.004

[4] L. Ohashi \& O. Louise. "Enhancing EFL Writing Courses with the Online Student Response System Socrative”. 国際経営 - 文化研究= Cross-cultural business and cultural studies, 19(1), pp. 135-145, 2015.

[5] I. Varannai, P. L. Sasvári \& A. Urbanovics. "The use of gamification in higher education: an empirical study". International Journal of Advanced Computer Science and Applications, 8(10), pp. 1-6, 2017. doi: 10.14569/ijacsa.2017.081001

[6] A. I. Wang, \& A. Lieberoth, A. "The effect of points and audio on concentration, engagement, enjoyment, learning, motivation, and classroom dynamics using Kahoot". In European Conference on Games Based Learning, 2016.

[7] D. Méndez-Coca, \& J. Sliško. "Software Socrative and smartphones as tools for implementation of basic processes of active physics learning in classroom: An initial feasibility study with prospective teachers". European Journal of Physics Education, 4(2), pp. 17-24, 2017.

[8] S. Pais, A. Pires, L. Chagas. "Enhancing student motivation with Kahoot! - A case study in English and Mathematics". Edulearn18 Proceedings, pp. 5518-5522, 2018. doi: 10.21125/edulearn.2018.1328

[9] T.D.V. Swinscow. Statistics at Square One (9th edition). London: MBJ Publishing Group, 1997.

[10] Bernal, A. M. Ares, J. Bernal, M. J. Nozal, and F. J. Sánchez, "Results of the use of Kahoot! gamification tool in a course of Chemistry," Proceedings of the 4th International Conference on Higher Education Advances (HEAd'18), 2018. doi: 10.4995/head18.2018.8179 
[11] D. H. Iwamoto, J. Hargis, E. J. Taitano, \& K. Vuong. Analyzing the Efficacy of the Testing Effect Using Kahoot ${ }^{\mathrm{TM}}$ on Student Performance. Turkish Online Journal of Distance Education, 18(2), pp. 80-93, 2017.

[12] V. Izquierdo-Álvarez, E. Lahuerta-Otero, and R. Cordero-Gutiérrez, "Kahoot, win the learning race," Proceedings of the Sixth International Conference on Technological Ecosystems for Enhancing Multiculturality - TEEM'18, 2018. doi: 10.1145/3284179.3284303 